\begin{tabular}{c} 
Volume and Issues Obtainable at Center for Sustainability Research and Consultancy \\
Responsible Education, Learning and Teaching in Emerging Economies \\
ISSN: 2708-4310 (E): 2708-4183 \\
Volume 1: No. 1, June 2019 \\
CSRᄃ \\
Journal homepage: www.publishing.globalcsrc.org/relate \\
\hline
\end{tabular}

\title{
Predictive Power of Socio Economic Status for Achievement Goal Orientation of Secondary School Students in Punjab
}

\author{
${ }^{1}$ Mumtaz Akhter \\ ${ }^{1}$ Professor of Education, University of Management and Technology, Lahore, Pakistan: \\ mumtaz.akhter@umt.edu.pk
}

\begin{tabular}{|c|c|}
\hline ARTICLE DETAILS & ABSTRACT \\
\hline $\begin{array}{l}\text { History } \\
\text { Revised format: May } 2019 \\
\text { Available Online: June } 2019\end{array}$ & $\begin{array}{l}\text { This study aimed at finding the effect of socio economic status of } \\
\text { students on their achievement goal orientation in the subject of } \\
\text { mathematics at secondary level in Punjab. Population of the study }\end{array}$ \\
\hline $\begin{array}{l}\text { Keywords } \\
\text { Socio Economic Status, } \\
\text { Predictive Power Of SES, } \\
\text { Achievement Goal Orientation }\end{array}$ & $\begin{array}{l}\text { was secondary school students and teachers in the province of } \\
\text { Punjab. Multi stage random sampling technique was used for the } \\
\text { selection of sample. Sample was consisted of } 874 \text { ninth grade } \\
\text { students ( } 428 \text { female and } 446 \text { male) from nine Districts of Punjab } \\
\text { by categorizing Districts according to its Human Development }\end{array}$ \\
\hline $\begin{array}{l}\text { JEL Classification: } \\
017,019\end{array}$ & $\begin{array}{l}\text { Index, into three categories. Four government schools, two girls and } \\
\text { two boys, were selected for data collection. Adapted questionnaire } \\
\text { "Achievement Goal Orientation Questionnaire (AGOQ)" was used } \\
\text { to get responses about achievement goal orientation of students. To } \\
\text { assess the socio-economic status of students various demographic } \\
\text { variables (i.e, father and mother' qualification and profession, } \\
\text { monthly income, area of their houses and income per month etc.) } \\
\text { were used. Regression analysis showed the predictive power of SES } \\
\text { for achievement goal orientation of students at secondary level in } \\
\text { Punjab. Findings were tabulated and recommendations were made } \\
\text { on the basis of findings. }\end{array}$ \\
\hline
\end{tabular}

(C) 2019 The authors, under a Creative Commons Attribution-

NonCommercial 4.0

Corresponding author's email address: mumtaz.akhter@umt.edu.pk

Recommended citation: Akhter, M., (2019). Predictive Power of Socio Economic Status for Achievement Goal Orientation of Secondary School Students in Punjab. Responsible Education, Learning and Teaching in Emerging Economies, 1(1), 9-18

DOI: $10.26710 /$ relate.v1i1.1117

\section{Introduction}

Achievement Goal Orientation (AGO) is a general theory of motivation. It emphasizes the fact that the goals a person holds have a significant effect on the way he/she tries to pursue the goals (Ames, 1992; Dweck, 1986). Since the last several decades many studies have been carried out on Achievement Goal Orientations and its associated variables (Dinc, 2010).

According to AGO theory there are two general patterns of adoption of goals, which students hold. One is learning goal orientation, which is also known as mastery goal orientation in achievement goal orientation 
literature. Other is performance goal orientation which is further divided in to performance-approach and performance avoidance goal orientation (Elliot \& Harackiewicz, 1996). Some also divided learning goal orientation in approach and avoidance dichotomy in their research (Elliot, 1999; Elliot \& McGregor, 2001; Pintrich, 2000a, Pintrich, 2000b). Students with mastery goal orientation focus on mastery of tasks and have desire to gain new skills. Learners with mastery-avoidance goal orientation want to be successful anyways, mostly by avoidance of being incorrect, striving not to misunderstand information related to passing criteria, or by completing tasks anyways.

Those who have performance-approach goal, they want to look competent as compare to others and try to obtain favorable judgments about their own ability from others. Students who have performanceavoidance goal orientation attempt to avoid unfavorable judgments about their competence and looking incompetent, mostly they try to stay away from difficult tasks (Elliot \& Harackiewicz, 1996).

Socio Economic Status (SES) is the amalgamation of background variables that represent the feature of the social structure in a society. There are several definitions of SES such as according to Oakes \& Rossi (2003), SES is the "differential access (realized and potential) to desired resources" and Hauser \& Warren (1997) defined it as "a shorthand expression for variables that characterize the placement of persons, families, households, census region, or other aggregates with respect to the capacity to create or consume valued goods in our society". Generally, SES is considered in the form of money and education.

Research identified direct as well as indirect effects of SES on students' success, which lead to the question of exactly which outcomes are related to SES and which factors of socio economic status, are more affecting these outcomes. Research has reported the effect of SES on achievement-related variables i.e., cognitive readiness, academic skills, academic adjustment and ability (e.g., Anderson \& Keith, 1997; Davies \& Guppy, 1997; Felner et. al., 1995; Leppel, Williams, \& Waldauer, 2001; Stipek \& Ryan, 1997). For example in a longitudinal research Stipek and Ryan (1997); and Stipek ( 2001) have found the significant relationship of SES (family income) with cognitive and academic skills in grade one and in playgroup and kindergarten SES was also associated with cognitive readiness. In another research Felner et. al., (1995) found correlation between SES and factors of academic adjustment, i.e. psychological adjustment; self-esteem; observed capabilities; depression; behavioral problems in classroom; rejection by the parents and social support by their family.

So, it can be concluded that SES has significant effect on a various achievement-related variables. Oakland et.al., (1994) in a study of Brazilian children reported the relationship between achievement motivation and SES, predominantly with family income. Koutsoulis and Campbell (2001) observed a direct effect of SES on students' educational goals.

These studies motivated the researchers to examine the factors that are effecting achievement goal orientations of secondary school students. Although the relationship between SES and motivation have been investigated, but achievement goal orientation has not been effectively examined. According to Kalisli, Finney and Horst (2006) there is paucity of research investigating the relationship between SES and motivation, as SES is linked to various achievement-related variables and achievement itself, it is important to uncover the relationship (or lack of relationship) between SES and achievement goal orientation. The relationships of SES with motivation and other achievement-related variables stressed the significance of investigating the SES in our academic setting. The study provided evidence about the extent to which SES can predict pattern of adoption of achievement goal orientations. The study also identified the predictive power of different factors of SES for the adoption of different goal orientations.

\section{Objectives}

Present study was conducted to achieve the following objectives:

- To identify the predictive power of different factors of SES for mastery-approach goal orientation 
- To discover the predictive power of different factors of SES for mastery-avoidance goal orientation

- To identify the predictive power of different factors of SES for performance-approach goal orientation

- To discover the predictive power of different factors of SES for performance-avoidance goal orientation

\section{Methodology}

This was a survey study in nature. In order to conduct the study following procedures were followed:

\subsection{Population}

Population of the study was consisted of students of class IX enrolled in government high schools (both boys and girls) of nine districts of Punjab.

\subsection{Sample and sampling technique}

In order to get representative sample for SES the districts were selected according Education Deprivation Index (HDI). According to Pakistan Social and Living Standards Measurement Survey PSLM (2011), by Jamal (2012), list of 36 districts of the Punjab was divided in to three strata with respect to Education Deprivation Indices (EDI), i.e. districts having high, medium and low EDI. Three districts were randomly selected from each stratum. From each district four government high schools (two boys, two girls') were selected. Subjects of the study were selected randomly from the students enrolled in ninth class of these schools. twenty five subjects were selected from each school. In this way one hundred subjects were selected from each district. Total number of subjects was eight seventy four (428 female and 446 male.

\subsection{Instrumentation}

Different demographic variables (father and mother' qualification and profession, monthly income, area of students' houses etc.) were used to assess the SES level of students. An adapted questionnaire "Achievement Goals Orientation Questionnaire (AGOQ)" adapted from "Pattern of Adaptive Learning", was used to assess students' goal orientations in the subject of mathematics. The reliability index of the scale AGOQ was 0.94 .

\subsection{Data Analysis}

Data was analyzed through SPSS. Regression analysis was done to assess the predictive power of SES for achievement goal orientation of students at secondary level. Results of the study are being presented in tables.

Table 1: Descriptive statistics

\begin{tabular}{|l|l|l|l|}
\hline Variables & Description & Details & Total \\
\hline Gender & Male & 428 & 874 \\
\cline { 2 - 3 } & Female & 446 & \\
\hline Age & Range & $13-18$ & 36 \\
\hline Schools & Male & 18 & \\
\hline & Female & 18 & \multirow{2}{*}{} \\
& High EDI & Lahore & \\
& & Chakwal & \\
\hline
\end{tabular}




\begin{tabular}{|l|l|l|l|}
\hline & Medium MDI & $\begin{array}{l}\text { Kasure } \\
\text { Okara } \\
\text { Jhung }\end{array}$ & 3 \\
\cline { 2 - 4 } & Low LDI & $\begin{array}{l}\text { Bakhar } \\
\text { Chiniot } \\
\text { Bahawalnagar }\end{array}$ & \\
\hline
\end{tabular}

Table 2|: Model Summary of regression analysis to identify the predictive power of SES for PGO

\begin{tabular}{|l|l|l|l|l|l|l|}
\hline Model & $\mathrm{R}$ & $\mathrm{R}$ Square & $\begin{array}{l}\text { Adjusted R } \\
\text { Square }\end{array}$ & $\begin{array}{l}\text { Std. Error of the } \\
\text { Estimate }\end{array}$ & $\begin{array}{l}\text { Sig. } \\
\text { Change }\end{array}$ & $\begin{array}{l}\text { Durbin- } \\
\text { Watson }\end{array}$ \\
\hline 1 & $.250^{\mathrm{a}}$ & .063 & .056 & 3.009 & .000 & 1.723 \\
\hline
\end{tabular}

a. Predictors: (Constant), Incomeinpoints, Area, Mprofession, Fprofession, Feducation, Meducation b. Dependent Variable: PGO

Table indicates the $\mathrm{R}$ value is 0.250 , which represents the simple correlation. It indicates the degree of correlation between Performance Goal Orientation (PGO) and Socio Economic Status SES. The $\mathrm{R}^{2}$ value indicates how much of the performance goal orientation, can be explained by SES. In this case, $6 \%$ variance in PGO can be explained, which is not high but table shows significant $\mathrm{F}$ change which indicated that the change in PGO can be explained significantly due to change in SES. The value of Durbin-Watson (1.72) shows that there is no serial correlation among the residuals.

Table 3: ANOVA to determine the level of significance of the predictive power of SES to assess PGO

\begin{tabular}{|l|l|l|l|l|l|l|}
\hline \multicolumn{2}{|l|}{ Model } & $\begin{array}{l}\text { Sum of } \\
\text { Squares }\end{array}$ & Df & $\begin{array}{l}\text { Mean } \\
\text { Square }\end{array}$ & F & Sig. \\
\hline \multirow{3}{*}{1} & Regression & 491.575 & 6 & 81.929 & 9.050 & .000 \\
\cline { 2 - 8 } & Residual & 7369.348 & 814 & 9.053 & & \\
\cline { 2 - 5 } & Total & 7860.923 & 820 & & & \\
\hline
\end{tabular}

a. Dependent Variable: PGO

b. Predictors: (Constant), Incomeinpoints, Area, Mprofession, Fprofession, Feducation, Meducation

The ANOVA table indicates that the regression model predicts the PGO significantly well. This table indicates the statistical significance of the regression model that was applied. Here, $p=0.000$, which is less than 0.05 , and indicates that, overall, the model applied can statistically significantly predict the PGO.

Table 4: Coefficients of variables to determine the predictive power of SES for PGO

\begin{tabular}{|c|c|c|c|c|c|c|}
\hline \multirow{2}{*}{\multicolumn{2}{|c|}{ Model }} & \multicolumn{2}{|c|}{$\begin{array}{l}\text { Unstandardized } \\
\text { Coefficients }\end{array}$} & \multirow{2}{*}{\begin{tabular}{|c}
$\begin{array}{l}\text { Standardized } \\
\text { Coefficients }\end{array}$ \\
Beta
\end{tabular}} & \multirow[b]{2}{*}{$\mathrm{T}$} & \multirow[b]{2}{*}{ Sig. } \\
\hline & & B & Std. Error & & & \\
\hline \multirow{5}{*}{1} & (Constant) & 10.752 & .723 & & 14.874 & .000 \\
\hline & Father education & -.022 & .067 & -.014 & -.329 & .742 \\
\hline & Mother education & .059 & .071 & .037 & .831 & .406 \\
\hline & Father profession & .071 & .084 & .031 & .848 & .397 \\
\hline & Mother profession & .031 & .127 & .009 & .247 & .805 \\
\hline
\end{tabular}




\begin{tabular}{|l|l|l|l|l|l|}
\hline Area of house & .517 & .124 & .142 & 4.160 & .000 \\
\hline Income per month & -.041 & .008 & -.201 & -5.459 & .000 \\
\hline \multicolumn{7}{|l|}{} \\
\hline
\end{tabular}

\section{a. Dependent Variable: PGO}

The Coefficients table provides information on each predictor variable. This gives the information to predict PGO from the factors of SES. It shows that the constant, House area and income per month contribute significantly to the model (reflected by the Sig. column). By looking at the $\mathbf{B}$ column under the heading Unstandardized Coefficients column, the regression equation can be presented as:

PGO $=10.752-.022$ (father education $)+.059$ (Mother education $)+.071$ (Father profession $)+0.031$ (mother profession) +.517 (house area) - .041 (income per month)

Table 5: Model Summary of regression analysis to identify the predictive power of LGO

\begin{tabular}{|l|l|l|l|l|l|l|}
\hline Model & $\mathrm{R}$ & R Square & $\begin{array}{l}\text { Adjusted R } \\
\text { Square }\end{array}$ & $\begin{array}{l}\text { Std. Error of the } \\
\text { Estimate }\end{array}$ & $\begin{array}{l}\text { Sig. } \\
\text { Change }\end{array}$ & $\begin{array}{l}\text { Durbin- } \\
\text { Watson }\end{array}$ \\
\hline 1 & $.388^{\mathrm{a}}$ & .151 & .144 & 2.968 & .000 & 1.551 \\
\hline
\end{tabular}

a. Predictors: (Constant), Incomeinpoints, Area, Mprofession, Fprofession, Feducation, Meducation b. Dependent Variable: LGO

The table above indicates the $\mathrm{R}$ value is 0.388 which represents the simple correlation between performance goal orientation and SES. The $\mathrm{R}^{2}$ value indicates how much of the performance goal orientation, can be explained by SES. In this case, $15 \%$ change on LGO can be explained on the basis of SES which is not high but table shows significant F change which indicated that the change in PGO can be explained significantly due to change in SES. The value of Durbin-Watson (1.551) shows that there is no serial correlation among the residuals.

Table 6: ANOVA to determine the level of significance of the predictive power of SES to assess LGO

\begin{tabular}{|l|l|l|l|l|l|l|}
\hline \multicolumn{2}{|l|}{ Model } & $\begin{array}{l}\text { Sum of } \\
\text { Squares }\end{array}$ & df & $\begin{array}{l}\text { Mean } \\
\text { Square }\end{array}$ & F & Sig. \\
\hline \multirow{3}{*}{1} & Regression & 1275.162 & 6 & 212.527 & 24.128 & .000 \\
\cline { 2 - 8 } & Residual & 7187.594 & 816 & 8.808 & & \\
\cline { 2 - 8 } & Total & 8462.756 & 822 & & & \\
\hline
\end{tabular}

a. Dependent Variable: LGO

b. Predictors: (Constant), Incomeinpoints, Area, Mprofession, Fprofession, Feducation, Meducation

The ANOVA table indicates that the regression model predicts the 1GO significantly well. This table indicates the statistical significance of the regression model that was applied. Here, $p=0.000$, which is less than 0.05, and indicates that, overall, the model applied can statistically significantly predict the LGO. 
Table 7: Coefficients of variables to determine the predictive power of SES for LGO

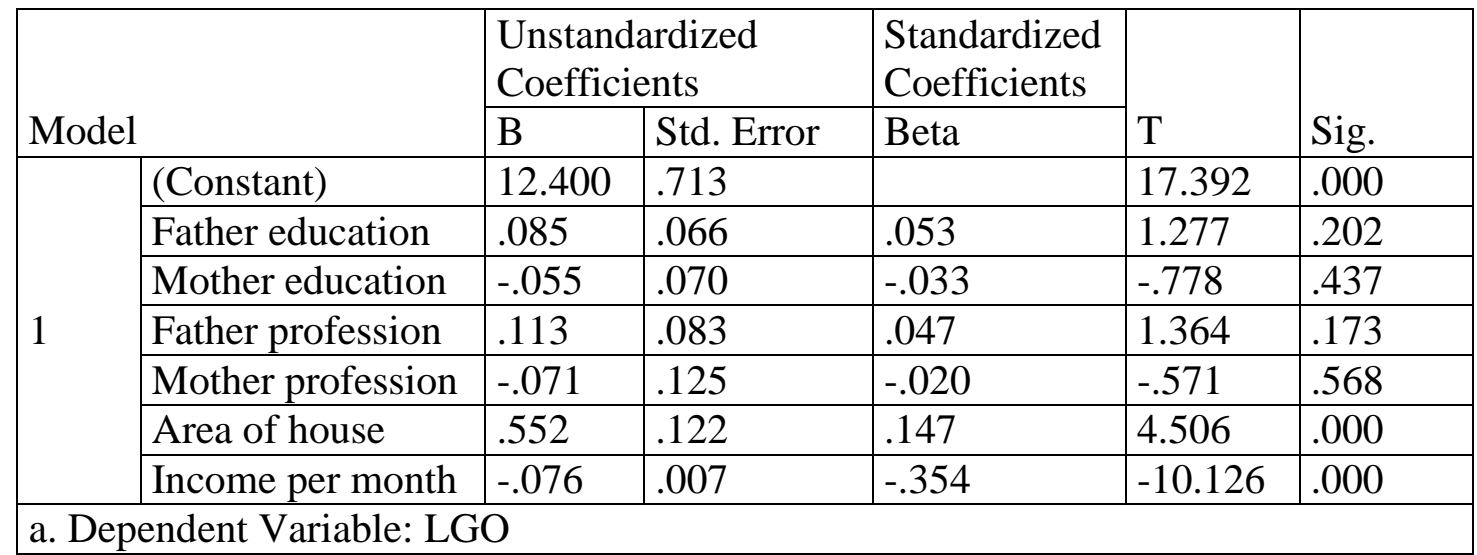

The Coefficients table provides information on each predictor variable. This gives the information to predict LGO from the factors of SES. It shows that the constant, House area and income per month contribute significantly to the model (reflected by the Sig. column). By looking at the B column under the Unstandardized Coefficients column, the regression equation can be presented as:

LGO $=12.4-.085$ (father education). .055 (Mother education) +.113 (Father profession) -0.071 (mother profession) +.552 (house area) -.076 (income per month)

Table 8: Model Summary of regression analysis to identify the predictive power of PAGO

\begin{tabular}{|l|l|l|l|l|l|l|}
\hline Model & $\mathrm{R}$ & $\mathrm{R}$ Square & $\begin{array}{l}\text { Adjusted R } \\
\text { Square }\end{array}$ & $\begin{array}{l}\text { Std. Error of the } \\
\text { Estimate }\end{array}$ & $\begin{array}{l}\text { Sig. } \\
\text { Change }\end{array}$ & $\begin{array}{l}\text { Durbin- } \\
\text { Watson }\end{array}$ \\
\hline 1 & $.108^{\mathrm{a}}$ & .012 & .004 & 2.749 & .144 & 1.853 \\
\hline
\end{tabular}

a. Predictors: (Constant), Incomeinpoints, Area, Mprofession, Fprofession, Feducation, Meducation

b. . Dependent Variable: PAGO

The table above indicates the $\mathrm{R}$ value is 0.108 , which represents the simple correlation. It indicates the degree of correlation between performance avoidance goal orientation and SES. The $\mathrm{R}^{2}$ value indicates how much of the performance goal orientation, can be explained by SES". In this case, $1 \%$ of the variance in PAGO can be explained, which is very low. which is not high table also shows that there is no significant $\mathrm{F}$ change which indicated that the change in PAGO cannot be explained significantly due to change in SES. The value of Durbin-Watson (1.853) shows that there is no serial correlation among the residuals.

Table 9: ANOVA to determine the level of significance of the predictive power of SES to assess PAGO

\begin{tabular}{|l|l|l|l|l|l|l|}
\hline \multicolumn{2}{|l|}{ Model } & $\begin{array}{l}\text { Sum of } \\
\text { Squares }\end{array}$ & df & $\begin{array}{l}\text { Mean } \\
\text { Square }\end{array}$ & F & Sig. \\
\hline \multirow{3}{*}{1} & Regression & 72.539 & 6 & 12.090 & 1.600 & .144 \\
\cline { 2 - 8 } & Residual & 6151.363 & 814 & 7.557 & & \\
\cline { 2 - 6 } & Total & 6223.903 & 820 & & & \\
\hline
\end{tabular}

a. Dependent Variable: PAGO

b. Predictors: (Constant), Incomeinpoints, Area, Mprofession, Fprofession, Feducation, Meducation

Table 9 indicates that the regression model does not predict the PAGO significantly. This table 
indicates that the applied regression model is not statistically significant. Here, $p=0.144$, which is greater than 0.05, and indicates that, overall, the model applied cannot statistically significantly predict the PAGO.

Table 10: Coefficients of variables to determine the predictive power of SES for PAGO

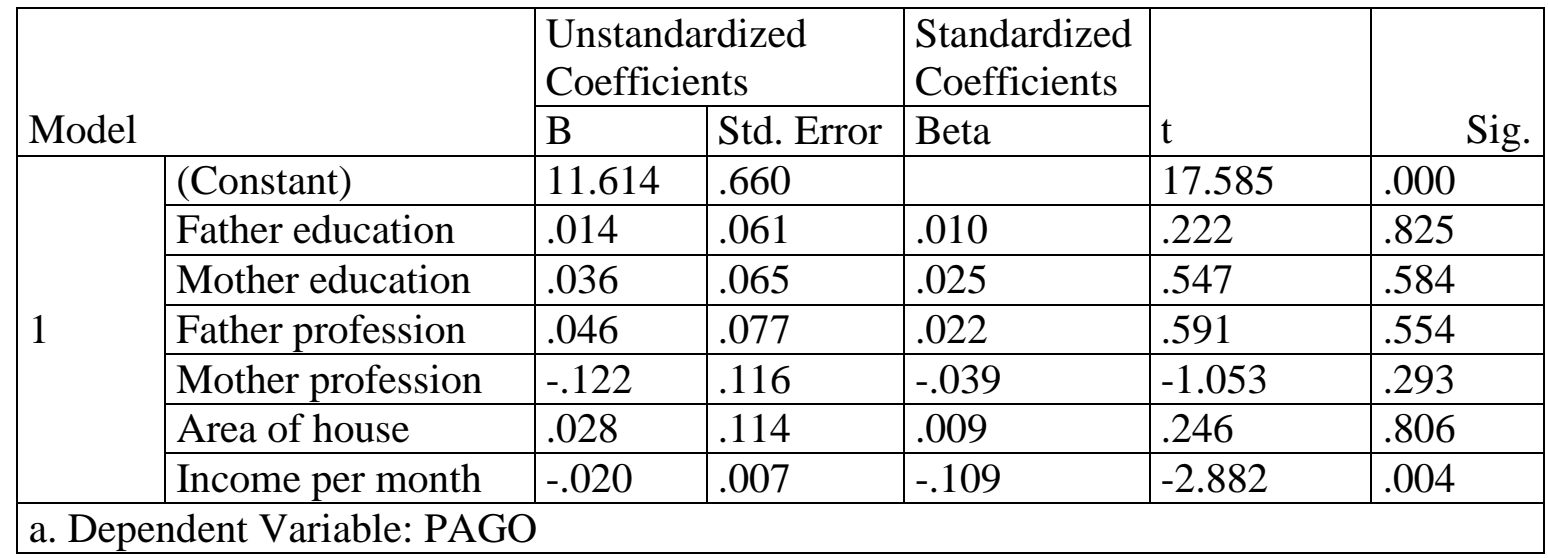

The table above provides information on each predictor variable. This gives the information to predict PAGO from the factors of SES. It shows that the constant and income per month contribute significantly to the model (reflected by the Sig. column). As overall applied model cannot statistically significantly predict the PAGO there is no need to develop regression equation.

Table 11: Model Summary of regression analysis to identify the predictive power of LAGO

\begin{tabular}{|l|l|l|l|l|l|l|}
\hline Model & $\mathrm{R}$ & R Square & $\begin{array}{l}\text { Adjusted R } \\
\text { Square }\end{array}$ & $\begin{array}{l}\text { Std. Error of the } \\
\text { Estimate }\end{array}$ & $\begin{array}{l}\text { Sig. } \\
\text { Change }\end{array}$ & $\begin{array}{l}\text { Durbin- } \\
\text { Watson }\end{array}$ \\
\hline 1 & .113 & .013 & .006 & 3.534 & .105 & 1.637 \\
\hline
\end{tabular}

a. Predictors: (Constant), Incomeinpoints, Area, Mprofession, Fprofession, Feducation, Meducation

b. Dependent Variable: LAGO

The given table indicates the $\mathrm{R}$ value is 0.113 , which represents the simple correlation. It indicates the degree of correlation between learning avoidance goal orientation LAGO and SES. The $\mathrm{R}^{2}$ value indicates how much of the performance goal orientation, can be explained by SES. In this case only $1 \%$ change can be explained on the basis of the model, which is very low. Table also shows that there is no significant $\mathrm{F}$ change which indicated that the change in LAGO cannot be explained significantly due to change in SES. The value of Durbin-Watson (1.637) shows that there is no serial correlation among the residuals.

Table 12: ANOVA to determine the level of significance of the predictive power of SES to assess LAGO

\begin{tabular}{|l|l|l|l|l|l|l|}
\hline \multicolumn{2}{|l|}{ Model } & $\begin{array}{l}\text { Sum of df. } \\
\text { Squares }\end{array}$ & $\begin{array}{l}\text { Mean } \\
\text { Square }\end{array}$ & F & Sig. \\
\hline \multirow{3}{*}{1} & Regression & 131.777 & 6 & 21.963 & 1.758 & .105 \\
\cline { 2 - 8 } & Residual & 10167.414 & 814 & 12.491 & & \\
\cline { 2 - 8 } & Total & 10299.191 & 820 & & & \\
\hline
\end{tabular}

a. Dependent Variable: LAGO

b. Predictors: (Constant), Incomeinpoints, Area, Mprofession, Fprofession, Feducation, Meducation 
The table 12 indicates that the regression model does not predict the LAGO significantly. . This table indicates that the applied regression model is not statistically significant. Here, $p=0.105$, which is greater than 0.05 , and indicates that, overall, the model applied cannot statistically significantly predict the LAGO.

Table 13: Coefficients of variables to determine the predictive power of SES for LAGO

\begin{tabular}{|c|c|c|c|c|c|c|}
\hline \multirow{2}{*}{\multicolumn{2}{|c|}{ Model }} & \multicolumn{2}{|c|}{$\begin{array}{l}\text { Unstandardized } \\
\text { Coefficients }\end{array}$} & \multirow{2}{*}{$\begin{array}{l}\text { Standardized } \\
\text { Coefficients } \\
\text { Beta } \\
\end{array}$} & \multirow[b]{2}{*}{$\mathrm{t}$} & \multirow[b]{2}{*}{ Sig. } \\
\hline & & B & Std. Error & & & \\
\hline \multirow{7}{*}{1} & (Constant) & 8.924 & .849 & & 10.510 & .000 \\
\hline & Father education & -.078 & .079 & -.044 & -.989 & .323 \\
\hline & $\begin{array}{l}\text { Mother } \\
\text { education }\end{array}$ & .160 & .084 & .087 & 1.913 & .056 \\
\hline & Father profession & .032 & .099 & .012 & .320 & .749 \\
\hline & $\begin{array}{l}\text { Mother } \\
\text { profession }\end{array}$ & -.147 & .149 & -.037 & -.986 & .324 \\
\hline & Area of house & -.061 & .146 & -.015 & -.421 & .674 \\
\hline & $\begin{array}{l}\text { Income } \\
\text { month }\end{array}$ & .014 & .009 & .060 & 1.594 & .111 \\
\hline
\end{tabular}

The Coefficients table provides information on each predictor variable. This gives the information to predict LAGO from the factors of SES. It shows that only constant contributes significantly to the model (reflected by the Sig. column). As overall applied model cannot statistically significantly predict the LAGO there is no need to develop regression equation.

\section{Conclusion}

On the basis of data analysis it is concluded that $6 \%$ change in PGO can be explained on the basis of variation in SES, though this is not a high value but result showed significant $F$ change which indicated that the change in PGO can be explained significantly due to change in SES. It is also evident that incomes per month and area of their houses have significant effect on the adoption of PGO. All other factors of SES, i.e. father and mother' qualification and profession etc. cannot predict the adoption of PGO. Similarly results also showed that $15 \%$ change on LGO can be explained on the basis of SES which is also not a high value but results showed significant $\mathrm{F}$ change which indicated that the change in LGO can be explained significantly due to change in SES.

As compare to this, change in SES cannot predict variance in PAGO and LAGO. Only $1 \%$ change in both orientations can be explained due to change in SES, which is statistically not significant. Results showed that all the factors of SES, i.e. father and mother' qualification and profession, monthly income, area of students' houses etc cannot predict the adoption of both orientations. So, it is concluded that adoption of both orientations cannot be predicted on the basis of SES of students at elementary level.

\section{Discussion}

Results showed that socio economic status of students can predict the adoption of learning approach and performance approach goal orientation only. It cannot be predict that what type of orientation students will adopt on the basis of mother and father qualification and their profession. Though the overall the predictive power is not strong enough ( $15 \%$ only), but it is statistically significant. Furthermore students having big houses only could be predicted to adopt learning goal orientation. And on the basis of income 
per month learning goal orientation could be predicted significantly, that is student with relatively less income per month can be predicted to adopt learning goal orientation as compare to students with higher income per month. Many studies also revealed the same results i.e. according to Kalisli, Finney and Horst (2006); Malik et. al. (2014) found that learning-approach goal orientation was endorsed more by lower income students, whereas performance-approach was endorsed more by higher income students. Similarly, results showed that socio economic status can predict the adoption of performance goal orientation. Endorsement of performance goal orientation cannot be predicted on the basis of mother and father education and their profession. Only Area of their houses and income per month can predict adoption of performance goal orientation. Though the overall the predictive power is not strong enough (6\% only), but it is statistically significant. SES cannot predict adoption of performance-avoidance and learning-avoidance goal orientation.

\section{Recommendation}

On the basis of findings it is recommended that:

- Teachers should adopt strategies to endorse learning goal orientation among students with high SES

- Teachers should held continuous meeting with the parents with higher income to guide them to provide facilitation to their kids on the basis of their learning. .

- Further variables should be investigated to identify their predictive power for achievement goal orientation.

\section{References}

Ames, C. (1992). Classroom Goals, Structures, and Student Motivation. Journal of Educational Psychology, 84, 261-271.

Anderson, E.S., \& Zeith, T.Z. (1997). A longitudinal test of a model for at-risk high school students. The Journal of Educational Research, 90, 259-267.

Davies, S. \& Guppy, N. (1997). Fields of study, college selectivity, and student inequalities in higher education. Social Forces, 75, 1417-1438

Dinc, Z. F. 2010. Relationship Between Achievement Goal Orientation and Physical Self-perception among Students Attending Physical Education Teaching. World Applied Sciences Journal 11 (6): 662-668

Dweck, C. (1986). Motivational Processes affecting learning. American Psychologist, 41, 1040-1048

Elliot, A. J., \& Harackiewicz, J. M. (1996). Approach and avoidance achievement goals and intrinsic motivation: a mediational analysis. Journal of Personality and Social Psychology, 70, 461-475

Elliot, A.J. (1999). Approach and avoidance motivation and achievement goals. Educational Psychologist, 34, 169-189

Elliot, A.J., \& McGregor, H.A. (2001). A 2 x 2 achievement goal framework. Journal of Personality and Social Psychology, 80, 501-519.

Felner, R.D., Brand, S., DuBois, D.L., Adan, A.M., Mulhall, P.H., \& Evans E.G. (1995). Socioeconomic disadvantage, proximal environmental experiences, and socioemotional and academic adjustment in early adolescence: Investigation of a mediated effects model. Child Development, 66, 774-792

Hauser, R.M. \& Warren, J.R. (1997). Socoioeconomic indexes for occupations: A review, update, and critique. Sociological Methodology, 27, 177-298.

Kalisli, Finney and Horst. (n.d). Does Socioeconomic Status Influence Achievement Goal Adoption? An Investigation of Group Difference Using Structured Means Modeling. Retrieved from https://www.jmu.edu/assessment/research/students/Kaliski,\%20Finney\%20\&\%20Horst_SES\%20and\%20a chievement\%20goal.pdf on 16-06-2014

Koutsoulis, M.K., \& Campbell, J.R. (2001). Family processes affect students'motivation, and science and math achievement in Cypriot high schools. Structural Equation Modeling, 8, 108-127

Leppel, K., Williams, M.L., \& Waldauer, C. (2001). The impact of parental occupation and socioeconomic status on choice of college major. Journal of Family and Economic Issues, 22, 373- 
394.

Malik, M., Hussain, A., Falima, G., Bashir, S., \& Safdar, M. (2014). Relationship of Self-concept, Socio Economic Status and Teachers' Instructional Practices with Achievement Goal Orientation of Secondary School Students. Paper presented in 3rd International Conference with theme 'Education in Pakistan: Practices \& Challenges' from 6-7 January, 2014 organized by University of Education, Township Campus, Township, Lahore.

Oakes, J.M., \& Rossi, P.H. (2002). The measurement of SES in health research: Current practice and steps toward a new approach. Social Science and Medicine, 56, 769-784.

Oakland, T., Wechsler, S., Benusan, E., \& Stafford, M. (1994). The construct and measurement of achievement among Brazilian children. School Psychology International, 15, 133-143.

Pintrich, P.R. (2000a). An achievement goal theory perspective on issues in motivation terminology, theory, and research. Contemporary Educational Psychology, 25, 92-104.

Pintrich, P.R. (2000b). Multiple goals, multiple pathways: The role of goal orientation in learning and achievement. Journal of Educational Psychology, 92, 544-555.

Stipek, D.J. \& Ryan, R. H. (1997). Economically disadvantaged preschoolers: Ready to learn but further to go. Developmental Psychology 33, 711-723.

Stipek, D.J. (2001) Pathways to constructive lives: The importance of early school success. In A. Bohart and D. Stipek (Eds.) Constructive and destructive behavior: Implications for family, school, and society. (pp.291-315). Washington DC: American Psychological Association. 